\section{Den sydøstasiatiske bog}

\section{Afforskningsbibliotekar Bent Lerbak Pedersen}

$\mathrm{P}$

å mange måder ligner bogværker fra Sydøstasien de indiske bøger. Man har især anvendt palmeblade som skrivemateriale, men også sten, ler, træ, ben, bark, papir og metal har været benyttet. I de tidlige tider blev sten, ler og metal mest anvendt, men fra omkring det 3 . årh. fvt. vandt brugen af palmeblade frem som det foretrukne skrivemateriale. Bark har sandsynligvis også være benyttet i tidlige tider, men bevarede eksempler på dette kendes ikke. Ben og metal har ganske givet været brugt tidligt, og fra Burma findes der et buddhistisk værk indridset på tynde guldplader fra det 5 . årh. evt. Papiret blev taget i anvendelse fra 1200-tallet, men kom ikke til at erstatte brugen af palmeblade.

\section{Bøger af palmeblade}

Thele Sydøstasien benyttede man sig af palmeblade helt op til 1900-tallet. Den traditionelle sydøstasiatiske bog består således af et bundt håndskrevne palmeblade mellem to beskyttende dækplader af hårdt materiale. For at sikre, at bladenes rækkefølge bibeholdes, er der boret et eller to huller igennem hele stakken af bladene, således at snore kan trækkes gennem disse huller og fastholde bladene. Håndskrifter skrevet på ben, metal og papir efterligner palmebladenes form, dvs. at de enkelte ark er i tværformat og beskrevet fra venstre mod højre langs den lange kant i horisontale linier under hinanden. Huller til snore kan ligeledes ses på bøger af metal, ben og papir.

Ligesom i det indiske område findes der to typer af palmeblade, der har været anvendt som skrivemateriale - først dem fra skærmpalmen (Corypha umbraculifera) og senere i løbet af 1500-tallet også blade fra palmyrapalmen (Borassus flabellifer). Skærmpalmen gror naturligt langs kyst-

Fig. 1. Abhidhanappadipika. Leksikalt vark af Moggallana (1100-tallet) skrevet på palmeblade i den tidlige del af 1800-tallet. Sproget er pali, skrevet med singalesisk skrift.

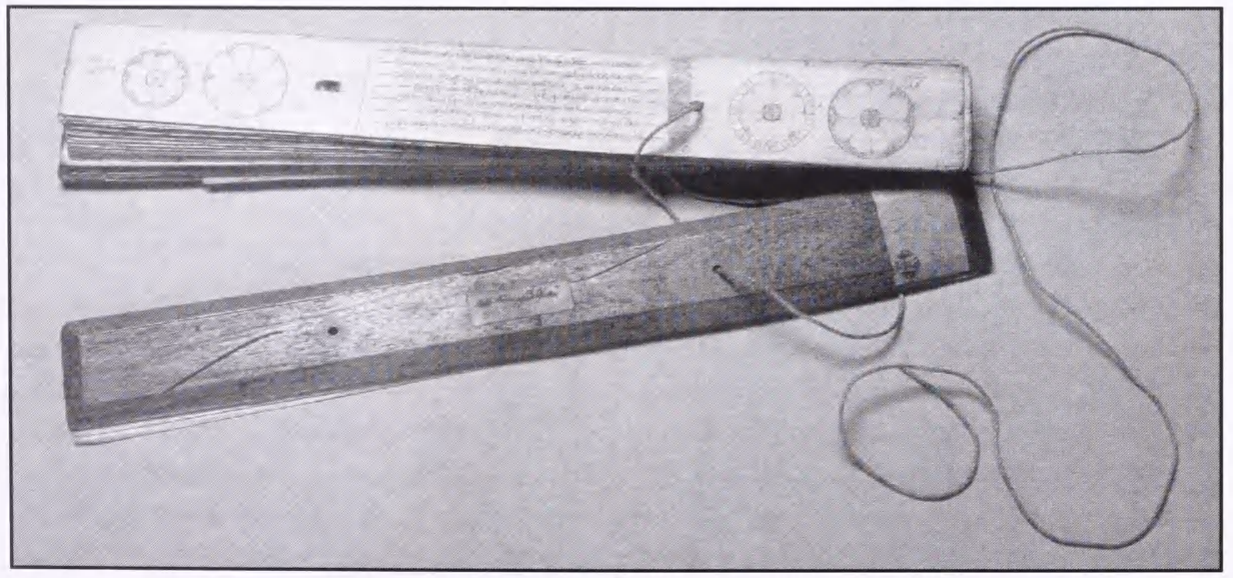


områderne, men den trives ikke $\mathrm{i}$ indlandet. Palmyrapalmen, der stammer fra Østafrika, kan gro i større områder end skærmpalmen. Dens blade er noget mindre end skærmpalmens, således at bøger skrevet på palmyrapalmens blade har relativt smalle blade og er sjældent over $40 \mathrm{~cm}$ lange. Blade fra skærmpalmen kan blive op til $1 \mathrm{~m}$ lange, men er sædvanligvis mellem 30 og $50 \mathrm{~cm}$ lange med en bredde mellem $6,5 \mathrm{og} 9 \mathrm{~cm}$.

Før palmebladene kunne bruges som skrivemateriale, skulle de bearbejdes. Først skar man bladene i passende størrelser, dernæst kogtes, tørredes og poleredes de. De færdige blade var glatte og fleksible, således at man enten kunne påføre tekst med en rørpen eller ridse den ind i bladene. De indridsede bogstaver blev ofte yderligere indgnedet med tusch for at gøre dem lettere at læse.

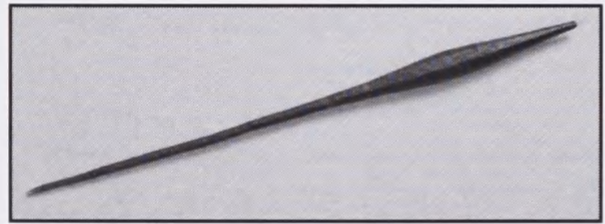

Fig. 2. Jerngriffel til at ridse tekst ind på palmeblade. Tidlig 1900-tal.

\section{Bøger af metal}

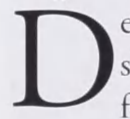
e værker, der kendes med metal som skrivemateriale, er alle i aflange tværformater, og er helt tydeligt en efterligning af palmebladene. Teksterne kunne påføres på tre måder. De kunne støbes, hvad dog var sjældent; de kunne ridses ind i bladene, som man især ser benyttet på guld- og sølvplader; og endelig kunne de males på metaloverfladen. Når der er tale om bemaling skete det på messing- eller zinkplader, der først blev dækket helt af et lag lak, hvorefter teksten påførtes i lak på dette overlag.
Denne sidste metode var især forbundet med burmesiske håndskrifter - herom senere.

\section{Stentekster}

ten har været betragtet som et mate-

riale, der kunne overleve naturens nedbrydning, og har således været benyttet til politiske og religiøse inskriptioner, man gerne ville have skulle overleve længe. Nogle af de ældste tekster har da også overlevet i sten. Et senere storstilet projekter med tekster indhugget på sten kan f. eks. opleves i Mandalay i Burma, hvor Kong Mindon i 1857 lod hele den buddhistiske tekstkorpus, Tripitaka, indhugge på 729 sten.

\section{Bambus og bark}

ekster indridset på bambus og skre-
vet på bark kendes fra Indonesien.
Det er især håndskrifter fra Batakfolket, der lever i det centrale Sumatra, som er kendte. Barken blev banket, kogt, tørret og poleret for at sikre en plan overflade, hvorpå man med en træpen kunne indskrive teksten med en tuschlignende væske. Batakfolket anvendte bark som skrivemateriale til egentlige værker, mens bambus blev mest benyttet til breve, beskyttelsesformularer og kalendere.. I Indonesien skrev man uden på selve bambusrørene i modsætning andre steder i Asien, hvor man splittede bambusen op i lange stokke. Bambusrørene blev derefter skåret op i stykker, nogle gange med et af bambusknæene bevaret, hvorved stykkerne blev særlige stabile.

\section{Bøger af papir}

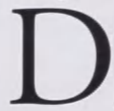
en papirproduktion, der kom i gang i de forskellige lande i Sydøstasien, var ofte baseret på brugen af det inderste lag af barken fra forskellige buske. Papirarkene fik en form som palmeblade, dvs. aflange stykker, hvor bredden ofte var 


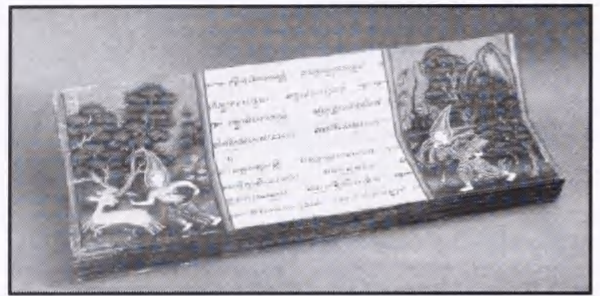

Fig. 3. Thai-haindskrift med buddhistiske tekster til recitation ved kremeringer. 1800-tallet.

en tredjedel af længden. Det var almindeligt at farve papiret sort, hvorpå man skrev med guld- eller sølvtusch. Hvis papiret blev anvendt som notesblokke, benyttede man sig af en blyantsformet fedtsten som skriveredskab. Afgnidningen (kridt) fra fedtstenen kunne gnubbes af, så det var muligt at anvende det samme papir igen, når man ikke mere havde brug for de tidligere nedskrevne noter.

Papirarkene kunne lægges som løse blade i bundter akkurat som palmeblade, og papirbundterne kunne ligesom palmebladene gennembores for at give plads til en eller to snore. Men det var dog mere almindeligt i Sydøstasien at lime papirarkene sammen langs de lange kanter til en lang sammenhængende papirbane. Denne bane blev foldet sammen som bælgen på en harmonika og en slags foldebog opstod. Teksten blev som regel skrevet ligesom på palmebladene langs med folderne (dvs. som på palmebladenes lange kant) i linier under hinanden. Der kan skrives både på for- og bagsiden af papirbanerne. Første og sidste papirark i en foldebog kunne forstærkes med et ekstra lag af papir, således at man ikke behøvede at fremstille to dækpladerne til en sådan foldebog.

Enkelte sydøstasiatiske papirbøger er samlet i arkblokke langs en fold $\mathrm{i}$ midten med en syning i ryggen. Denne type af bøger ses i Kashmir og Nepal fra 1400 - tallet og fik yderligere en udbredelse med europæernes ankomst til Sydøstasien i 1800tallet. Nogle af denne type bøger kan minde om kodeks-formen, der er almindelig i Europa i dag, har tekster eller illustrationer anbragt langs de øvre og nedre sider i bogen, således at bladene i bogen vendes fra neden og opefter; andre har teksten eller illustrationerne placeret i 90 grader vinkel til ryggen. Denne placering kan dels være inspireret af den islamiske bog fra Indien og dels fra vesterlandske bøger.

\section{Dekorationer og billeder}

Imindeligvis placeredes teksten på
papirbøgerne som på palmeblade i
tekstblokke med en vis margen, således at slid på kanterne ikke berørte tekstområdet. Illustrationer var derimod ofte lagt helt ud til kanten af palmebladene og papirarkene. Det var ganske besværligt at fremstille illustrationer direkte på palmeblade især, når det drejede sig om indridsning. Man kunne lægge et overfladelag på palmebladene, oftest et lag lak, hvorved man relativt let kunne påføre dekorationer og billeder, men det var en langsommelig proces og kostbar. Det var enklere at udføre dekorationer i papirbøger, da man kunne påføre dem direkte på papiret uden forarbejdning. Dog ser man tit, at fine farverige illustrationer først havde fået en slags grunding, før man påførte de farvede illustrationer.

Enkle illustrationer eller dekorationer er udført i samme tusch som teksten, og de kan fylde en del af et ark eller udfylde et helt eller to ark. Hvis det drejer sig om farvede illustrationer placeres de enten som helsidesdekorationer eller lægges i afgrænsede blokke på papirarkene. Disse blokke er ofte placeret for hver ende af arkene men kan også forekomme på midten af arkene. Helsidesdekorationer fylder tit mere end et 


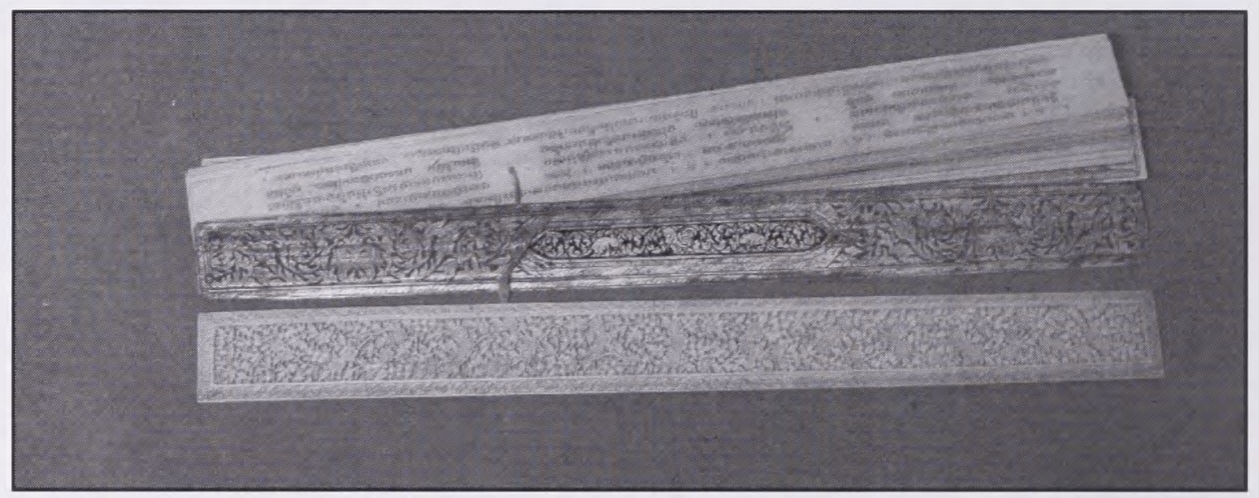

Fig.4. Dakplader fra Cambodja af elfenben med dybe dekorative udskaringer af ranker med dyr og fugle. Sen 1800-tal.

ark i en foldebog. Derved får man bedre mulighed for at udføre fine detaljerede illustrationer, og man kan skabe en hel føljeton en slags tegneserie.

Når håndskrifterne indeholder få illustrationer, er de ofte anbragt i spalter over to ark, der netop kan ses samlet i åben stand. Uden om selve illustrationerne ligger der gerne en dekoreret bort, der for det meste består af stiliserede blomster eller ensfarvede bånd. Denne type af illustrerede bøger består sædvanligvis af ufarvet papir, så teksten står frem i sort på hvidgulligt papir i modsætning til illustrationernes farvede baggrunde.

\section{Beskyttelse af bøger}

Demstillingen af bøger har været relativ -1 kostbar, f.eks. kunne en skriver kun producere tre til fire palmeblade med tekst om dagen. Derfor ville man gerne beskytte håndskrifterne mod skader. Man lagde ofte palmeblade og nogle gange også papirbøger mellem to dækplader. Disse dækplader kunne være af træ, elfenben eller metal og var en lille smule større end selve bladene. Træ var det mest almindelige, mens elfenben og metal var forbeholdt særlige vær- difulde bøger. Dækpladerne havde undertiden komplicerede dekorationer, påmalede eller udskårede ydersider, og i enkelte tilfælde også på indersiden. Udskæringerne i

Fig. 6. Typisk Thai bogskab dekoreret med Buddhafigurer i guld pa sort lak bund. 1931.

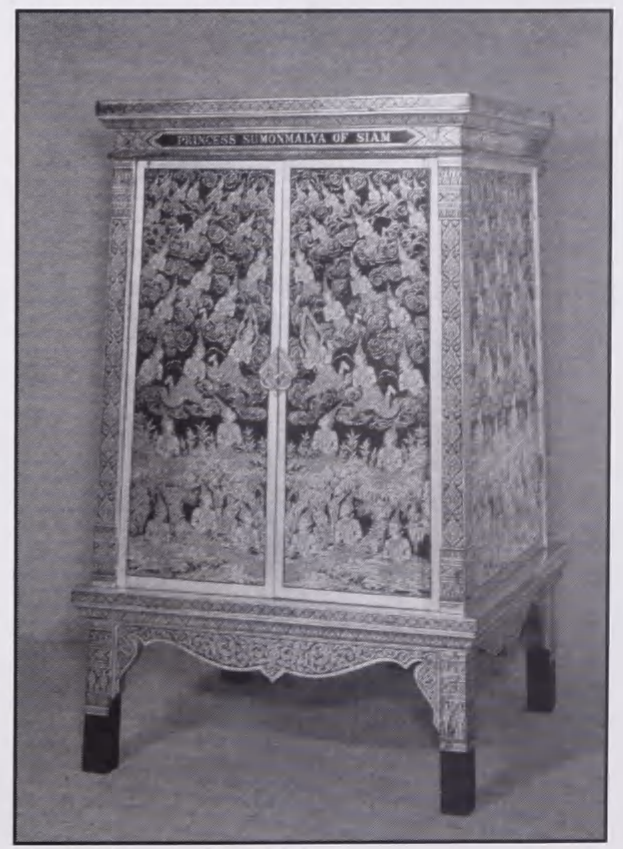




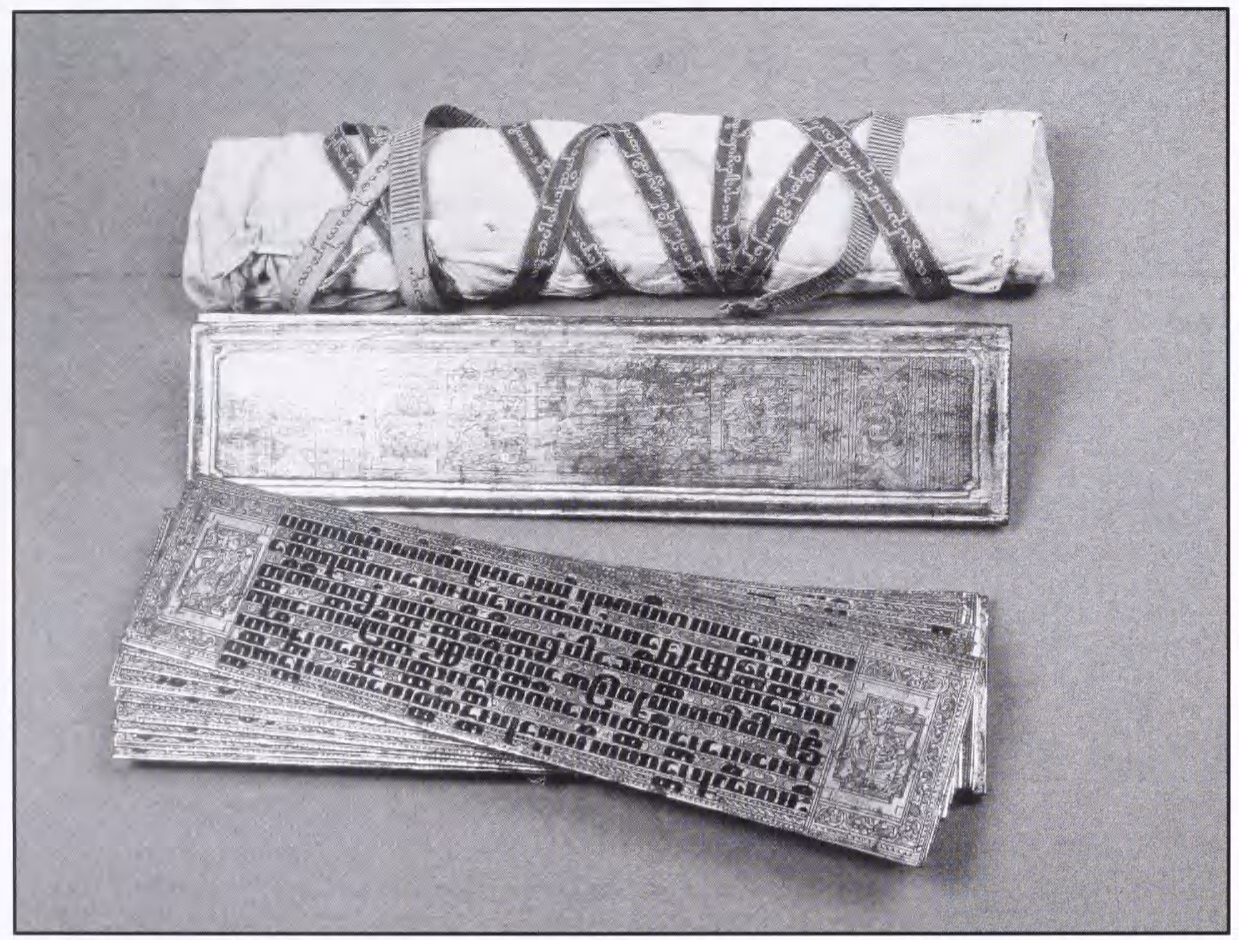

Fig. 5. Burmesisk håndskrift på lakerede messingplader. Denne Kammavaca-tekst (regler for munke) er skrevet på pali i burmesisk skrift. 1800-tallet. Øverst ses et udekoreret svob omviklet af et vavet bånd med verkets titel.

elfenbensplader var som regel mest detaljerede, da det var mere besværligt, og undertiden umuligt, at fremstille de fine detaljer i træ og metal.

Det var også almindeligt at skåne det øverste og nederste beskrevne blad mod slid ved at lægge et til to ubeskrevne blade mellem dem og dækpladerne, som et slags smudsblad. For yderligere at værne håndskrifterne mod skader lagde man dem inklusive dækpladerne i et klæde, der ofte var fint dekoreret. Bogen blev lagt diagonalt på dette svøb, som holdtes på plads med et bånd, der kunne være dekoreret eller ornamenteret med tekstlinier. Tekstlinierne kunne indeholde titlen på bogen, være en beskyttelsesformular eller indeholde navnet på den per- son, der havde ladet håndskriftet fremstille. Svøbene og båndene indeholdt ofte farvestoffer, der holdt insekter væk fra bøgerne. Både i private hjem, templer og kongelige paladser blev bøgerne placeret $\mathrm{i}$ bogskabe, dels for at skabe orden i de mange bøger men også for at beskytte bøgerne mod overlast. Disse skabe havde desuden det indre bemalet med farvestoffer, hvori der indgik kemikalier, som beskyttede mod insekter. Bogskabene kunne være meget fint formet; nogle som små pagodelignende skabe, andre som mere enkle firkantede møbler. De var som regel altid overdådigt ornamenteret med udskæringer eller med dekorationer i guldfarve.

Ud fra Det Kongelige Biblioteks 


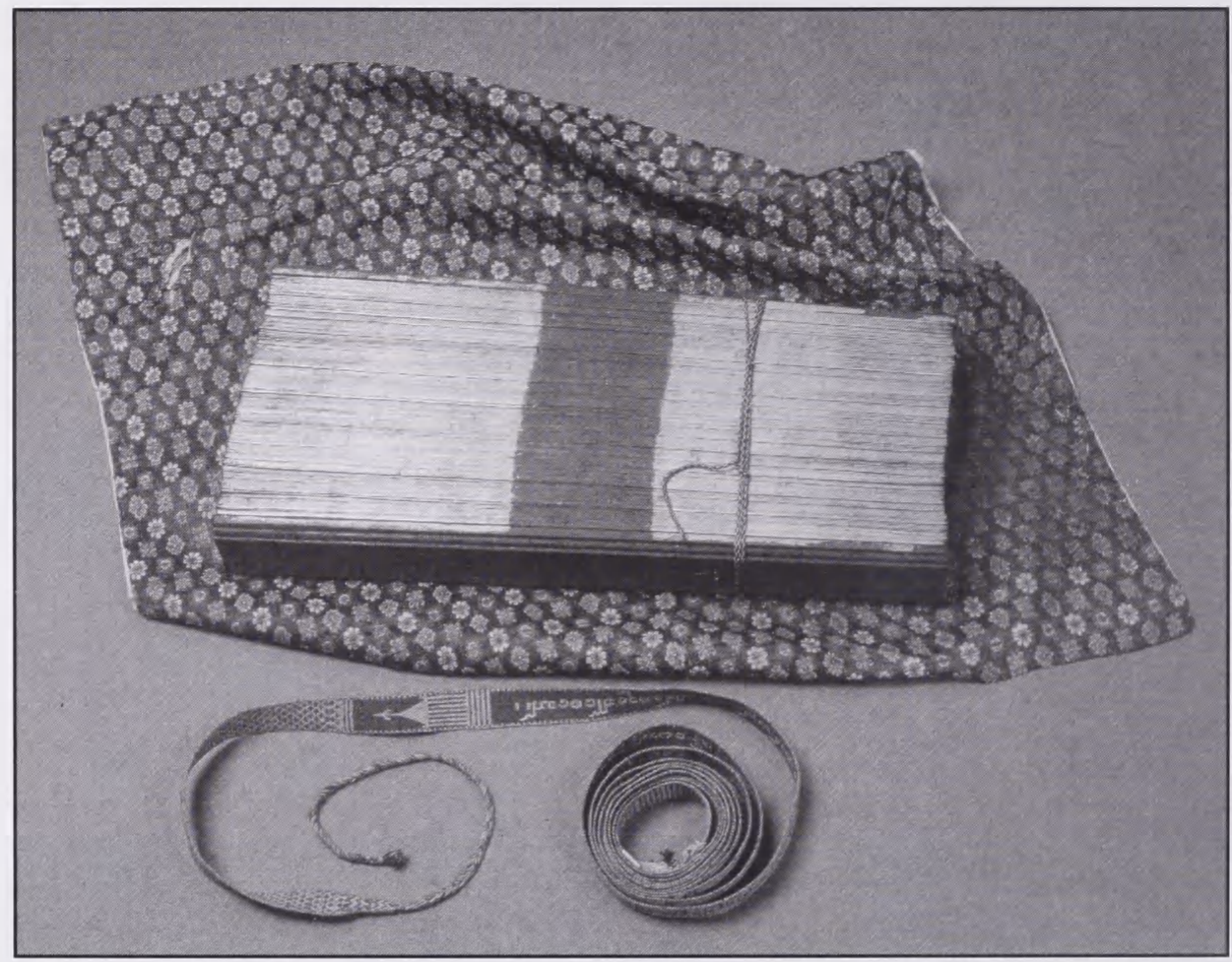

Fig. 7. Burmesisk buddhistisk håndskrift på palmeblade. Dhannapada-atthakatha-nissaya (buddhistiske fortallinger) skrevet på pali i burmesisk skrift. Farvningen af palmebladenes kanter ses tydeligt helt ud over dakpladernes kanter. Dateret 1874.

samlinger kan også de forskelle, der findes i de forskellige sydøstasiatiske landes bogkulturer, studeres.

\section{Burma}

$\mathrm{D}$ en burmesiske skrift, der er et alfabet, kendes i inskriptioner fra den tidlige del af 100-tallet. Skriften blev udviklet på basis af Mon- og Braminskriften fra Indien. Der findes to hovedvarianter: en rund stil, og en firkantet stil, som man ser benyttet til pragthåndskrifter, hvor det er venerationen for Buddhismen, der er det mest vigtige, og ikke tekstens indhold som brugsgenstand. Før den burmesiske skrift blev udviklet, anvendte man sig af især sydindiske skrifter. I det burmesiske område findes desuden andre folkeslag med deres egen skrift som f.eks. Shanfolket. Dette behandles ikke i denne artikel.

De fleste håndskrifter fra Burma er palmeblade, hvorpå teksten er indridset. Palmebladene er relative smalle $(48-61 \mathrm{~cm}$ lange og 5-6 cm brede) og er almindeligvis beskyttet af en øvre og nedre dækplade. Papirbøger kom først rigtigt $\mathrm{i}$ anvendelse i 1800-tallet, og var på mange måder fremstillet ligesom de foldede papirbøger fra Thailand. Brugen af papir til bøger var især knyttet til illustrerede værker, da det var enklere at dekorerede en papirflade end et eller flere palmeblade. 


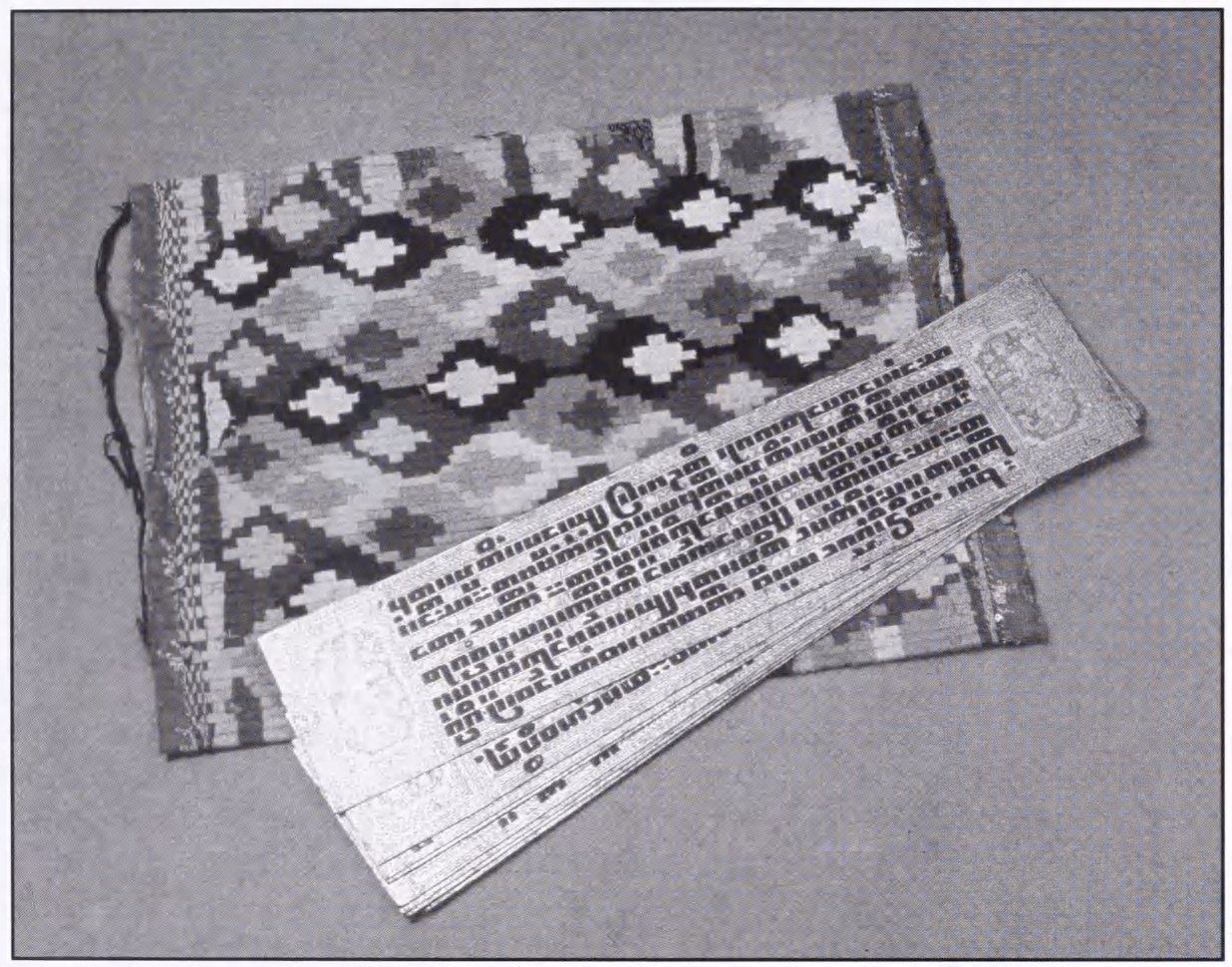

Fig. 8. Burmesisk buddhistisk håndskrift på lakerede palmeblade svobt i en bambusmåtte indhyllet i et vavet stof. Kammavaca-tekst (regler for munke) skrevet på pali i burmesisk skrift. Slutningen af 1700-tallet.

Det var almindeligt i Burma at farve den sammenlagte palmebladsblok, dvs. på kanten af alle bladene, med et rødt felt i midten og to guldfelter uden om på resten af håndskriftets kant. Undertiden indgår dækpladerne i denne farvning. I fà tilfælde optræder to dekorative blomsterranker uden om det røde felt i midten af tekstblokken. Nogle af de øvre dækplader er dobbelt så tykke som den nederste plade og har fået udskåret en enkel profil hele vejen rundt.

En del af palmebladsskrifterne har fået forsiden på første blad dekoreret med både figurer, plante- og geometriske mønstre. Sædvanligvis placeres figurerne, såsom fugle og vogterfigurer, i paneler, men særlige fine eksempler har en hel billedscene, hvor figurerne slynger sig ind i hinanden. Illustrationer blev malet med guldtusch på en grund af rødbrun lak. Det var udbredt i Burma at lægge et lag rødbrunt lag lak både på palmeblade og metalblade før man dekorerede med guld.

De fleste håndskrifter er svøbt i et klæde eller en flettet måtte omviklet af et vævet bånd. Fletningen har som basis smalle bambusstokke, der er indhyllet med vævede tekstiler. Både klædesvøbene og de vævede måtter har geometriske mønstre i ret kraftige farver.

I pragthåndskrifterne var skrivematerialet, der kan være palmeblade eller 

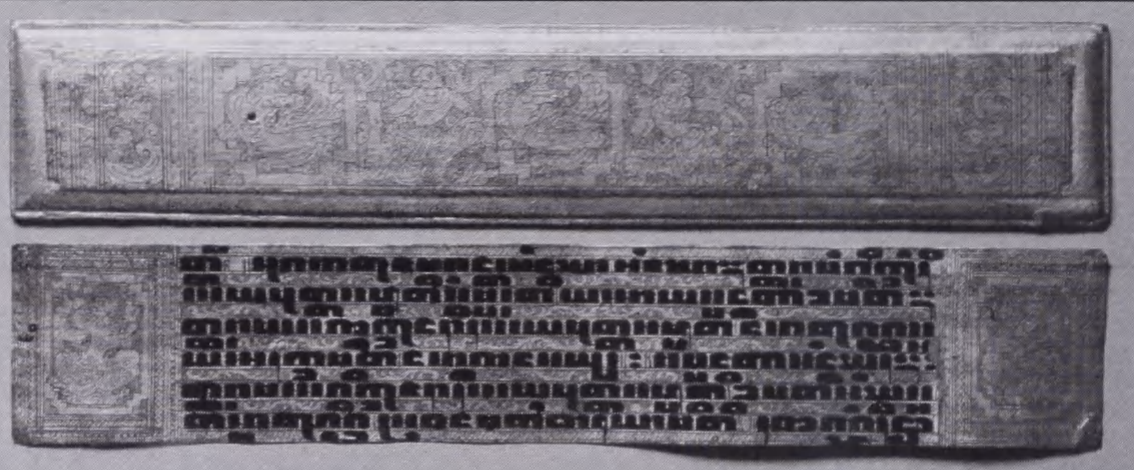

Fig. 9. Burmesisk buddhistisk håndskrift pa lakerede messingplader. Kammavaca-tekst (regler for munke) skrevet på pali i burmesisk skrift. 1700-tallet eller det tidlige 1800-tal.

metalblade, grundet med rødbrun lak og i få tilfælde med sort lak, som dækker begge sider af de enkelte blade. Oven på dette har man dekoreret enderne med figurer, plantemønstre og geometriske mønstre i guldtusch. I midten påførtes selve teksten, der var malet med et tykt lag sort lak på en bund af guld eller sølv oven på den rødbrune grund. De første blade har kun teksten i centrum af bladene med mange dekorative elementer uden om, mens teksten på resten af bladene udfylder hele overfladen. Mellem de sorte tekstlinier ses mønstre malet med guldtusch i enkle geometriske eller plantelignende former.

I meget sjældne tilfælde har man anvendt tøj, f.eks. fra en berømt munk, som skrivemateriale. Klædet blev skåret op i palmebladsform, gjort stift og lakeret. Selve teksten og dekorationerne på hver side af teksten kunne så skabes af indlagt perlemor. Der er også eksempler på endnu mere ekstravagante værker, hvor selve bladene i bogen er fremstillet af elfenben. Disse blade blev derefter dekoreret med mønstre og figurer i guld mens teksten var skrevet i sort lak.

Det er helt klart, at denne type af håndskrifter har været beordret udført med det formål at sikre, at giveren ville få en forbedret karma, der skulle hjælpe vedkommende til et bedre liv efter genfødslen. Hovedparten, hvis ikke alle, indeholder tekster af buddhistisk karakter. Det er ligeledes muligt at brugen af metal, messing og zink som skrivemateriale ville give endnu bedre karma, da man må formode at metal bliver bevaret længere end palmeblade. Tekster indridset på guld eller sølv var meget kostbare og var formodentlig kun udført for meget rige personer i det burmesiske samfund.

Dækpladerne for denne type af fine håndskrifter er ofte af træ grundet med rødbrun lak, mindre hyppigt i sort lak, og påført dekorationer i guldtusch ligesom skrifternes enkelte blade. Dekorationerne omfatter ligeledes plantemønstre, geometriske $o g$ figurer og alle typer kan kombineres eller består af en eller to af typerne.

\section{Thailand}

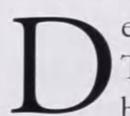
er findes to typer af håndskrifter i Thailand før 1900-tallet: palmeblade og foldede papirbøger. Begge medier kan være illustrerede, men det er mest almindeligt i de foldede papirbøger. De fleste af palmebladene har størrelse på $60 \times 6$ 


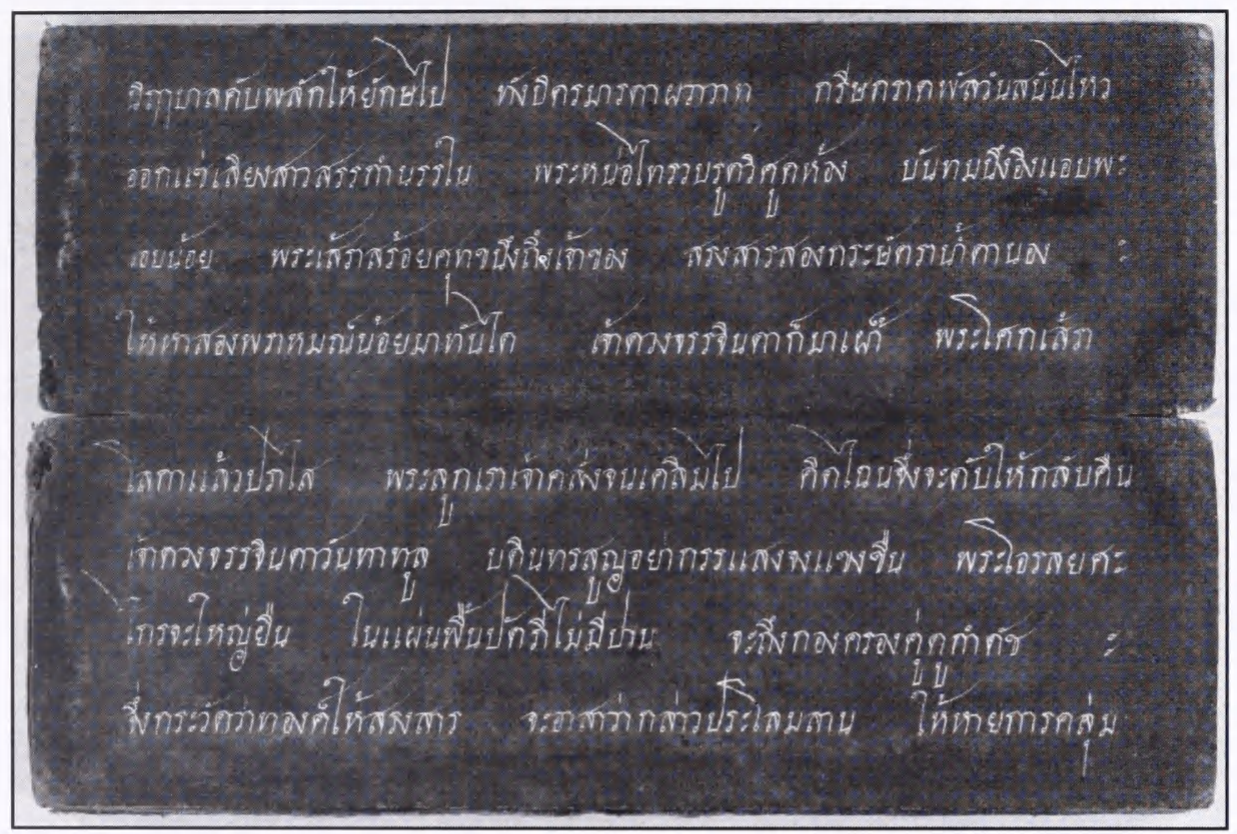

Fig. 10. To sider fra romanen Târavan. Thaihaindskrift på sort farvet papir. Anden halvdel af 1800-tallet.

$\mathrm{cm}$, mens papirbøger kan variere fra ca. 33 36 lange og 11-12 cm brede. Teksterne skrives fra venstre mod højre og sædvanligvis i linier langs den lange kant. På palmeblade skrives teksten på for-og bagsiden fortløbende, mens de i papirbøgerne først løber på forsiden gennem alle folderne for at kunne fortsætte på bagsiden af hele papirbanen. Teksten på palmeblade kan både ridses ind med en griffel og skrives i tusch med en pen, dog er det mest almindeligt at teksten ridses ind. Den indridsede tekst bliver gnedet med lampesod for at gøre den let læselig. Hvis en tekst med tiden afbleges, kan man igen gnide et ny gang lampesod ind. Dekorationer på palmeblade kan ridses ind eller lægges som maleri, og de dækker som regel kun en side af et blad. På foldebøgerne kan dekorationer fortsætte fra en side til den næste og sågar fylde flere sider, så man har en lang fortløbende illustration.
Dækplader for palmebladsbøger er for det meste af træ, og de fineste af dem er lakerede med guld- eller sølvtusch-illustrationer. Illustrationerne er som oftest buddhistiske figurer på en baggrund af planter, eller de kan være fugle og dyr mellem bladranker. I særlige tilfælde er der yderligere indlagt blomster dekorationer i perlemor. En del af de øverste dækplader er let konvekse.

Thaiskriften blev udviklet i 1200-tallet fra den indiske og cambodjanske skrift, og den fremstår i en ret firkantet stil med mange skarpe kanter. Dog findes der en nordthailandsk skrift, kaldes tham, som er mere rund i formen med tydelig inspirationskilde i den cambodjanske skrift. De fleste buddhistiske tekster er skrevet på pali med thaibogstaver ligesom det ses i Burma. Teksterne på palmeblade er for det meste netop buddhistiske, mens tekster på papir er både religiøse og sekulære. 


\section{Papirbøger}

$\mathrm{P}$ apir fremstillet i Thailand baseres på den indre del af barken af en busk, der på thai hedder khoi (Steblus Asper). Papiret fremstilles i relative store ark, der foldes og limes sammen til lange baner, således at en foldebog opstår. En del af papirproduktionen blev farvet med lampesod, og for at teksten og illustrationerne kunne læses og ses, skrev man med guldtusch, sølvtusch, gul tusch eller kridt. Rigt farvede illustrationer fandtes mest på ufarvet papir, hvor dekorationsfladen først var blevet grundet med en farve hvorpå illustrationerne maledes.

For at beskytter papirbøgerne kunne man lime et ekstra lag papir på for-og bagsiden. For at gøre dette ekstra lag endnu mere holdbart lakerede man det, sædvanligvis sort. Ofte lagde man en profillinie et stykke inde på papiret hele vejen rundt, således at der opstod en relieframme.

\section{Laos}

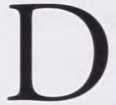

en laotiske skrift, der kendes fra 1200 -tallet, er et alfabet og minder meget om den thailandske, men skriften har sine egne varianter af bogstaverne. Almindeligvis skrev man på palmeblade, og bladene er typisk $60-40 \mathrm{~cm}$ lange og 4-4,5 cm brede. Teksterne er sædvanligvis indridsede, og man finder ofte små dekorative elementer i skriften som f.eks. fiskelignende figurer. De færdige indridsede tekster var ligesom i Thailand indgnedet med lampesod for at gøre bogstaverne tydelige. De fleste buddhistiske skrifter fra Laos var skrevet på pali med den tidligere nævnte tham-skrift fra Thailand. Dette fænomen gør det undertiden vanskeligt at skelne mellem pali-tekster fra Thailand og Laos. Dog er mange af teksterne skrevet med tham-skiften fra Laos.

Kanten af bladene er farvet ligesom i Burma. De kan have blomstermønstre i bånd, være helt røde- eller guldfarvet eller have en rød midte omgivet af guld. Bladblokkene kan være indsvøbt i stof eller i stofomviklede bambusmåtter ganske ligesom i Burma. Som noget helt særligt har mange af håndskrifterne en pegepind fæstnet til en af snorene, der holder bladene sammen. Pegepindene er som regel af træ, og de er

Fig. 11. Buddhistisk håndskrift på palmeblade i Tham-skriften. Pathamamulamuli (Om verdens opståen). Dateret til 1835.

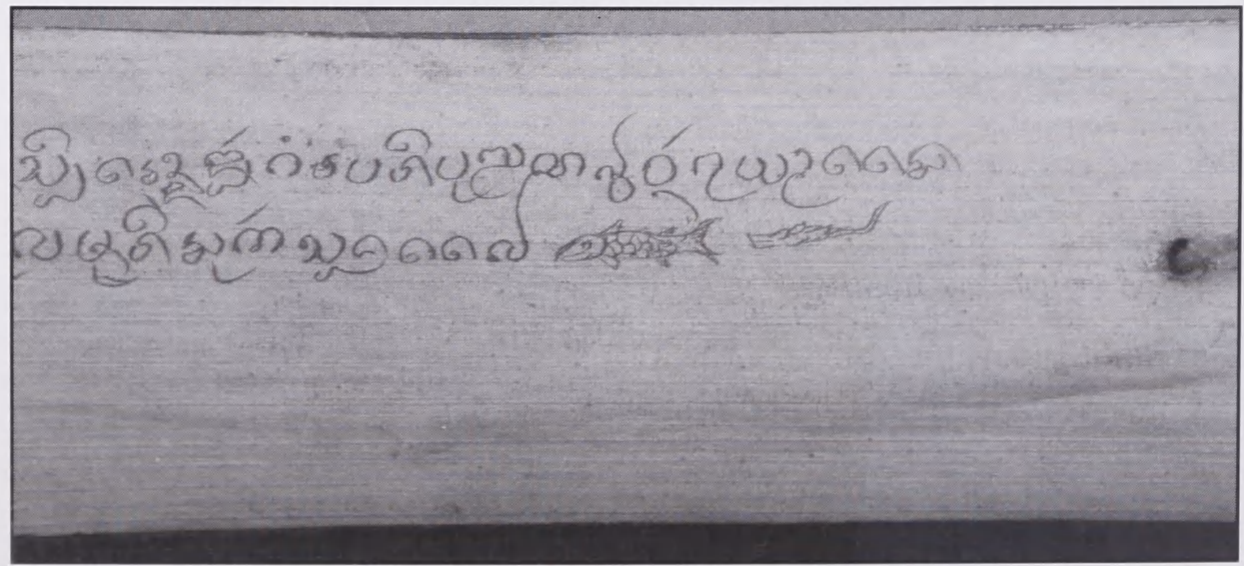




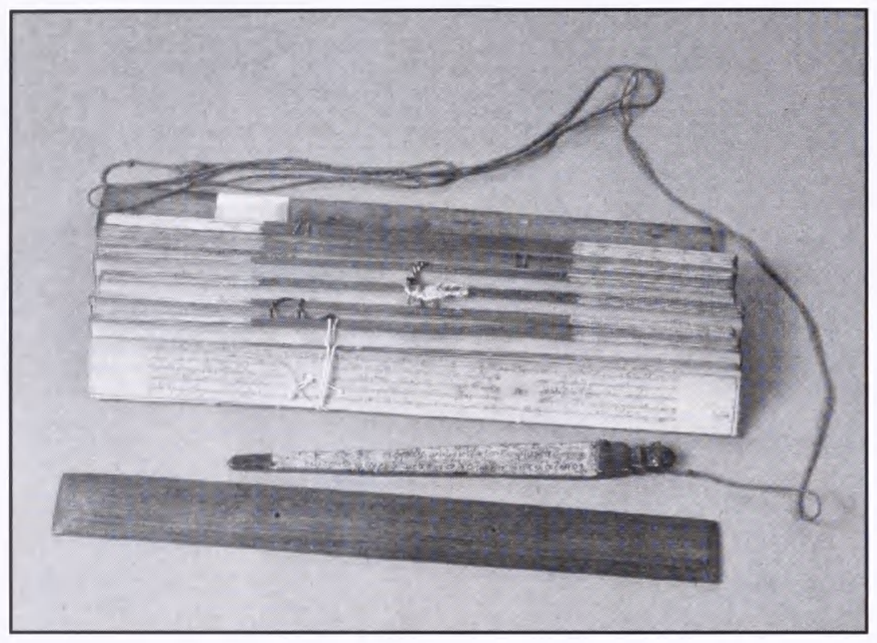

Fig 12. Laos 75. Buddhistisk palmehåndskrift fra Laos med pegepind. Arunavati (tekst om kosmos) skrevet på laotisk. 1800-tallet.

bemalet i sort, rød og/eller guldtusch, men mere enkle udførte pegepinde i træ eller bambus findes tillige. Inskriptioner er ridset ind i pindene eller påmalet. Disse inskriptioner relaterer sig til håndskriftets tekst. En del af pegepindene er udskåret i den ene ende med en pagodelignende figur, mens den anden ende er tilspidset. Pindene kan også anvendes som bogmærker. De kan være ganske lange men er altid kortere end selve palmebladene i håndskriftet.

Nogle få buddhistiske håndskrifter fra Laos er skrevet på ufarvet papir. Denne type af skrifter er nedskrevet på fol- dede papirbaner i aflangt tværformat ligesom det ses i Thailand. De beskyttes af dækplader i træ, der som regel er bemalet med rød eller sort og undertiden har dekoreringer i guldtusch ligesom på dækpladerne, der beskytter palmebladshåndskrifterne.

Dækpladerne er oftest af træ, i sjældne tilfælde med dekorationer baseret på dyr og fugle mellem plante- og blomstermønstre i geometriske former. Mønstrene er ofte udfort i guldtusch med andre farver som kontraster i detaljerne, nogle gange med indlagt farvet glas som f.eks. kronblade i geometrisk udformede plantemønstre i fint ud-

Fig. 13. Sortlakeret dakplade fra Laos med monstre i guld. Kammavaca-tekst (regler for munke) skrevet på pali i laotisk skrift. 1800-tallet.

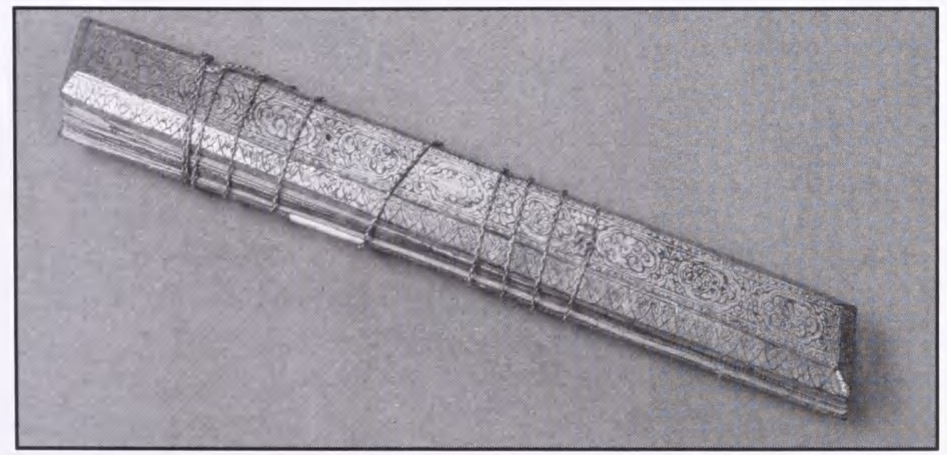


skåret kartoucher. Dækplader med dekorationer er sædvanligvis lakeret sort, både på yder- og indersiden. Nogle af dem har yderligere fået ydersiden farvet rød, hvorpå dekorationer har været påført, ligesom man kan se det direkte på den sorte lak. I stedet for at male dekorationerne, kan de indridses $\mathrm{i}$ baggrundsfarven, bl.a. gennem det røde farvelag til den sorte lak, ligesom det ses på pegepindene.

\section{Cambodja}

$\mathrm{K}$ hmerfolket i Cambodja fik deres skrift udviklet i 500-tallet, altså meget tidligere end i resten af Sydøstasien. Ligesom i de andre lande i Sydøstasien var palmebladsbøger det mest almindelige. Teksten var som regel indridset med efterfølgende indgnidning af sod. Kanten af den samlede tekstblok kunne ligesom på burmesiske palmebladsbøger være farvet i guld, nogle gange også i rød.

Dækplader er ofte i træ, men også plader i udskåret elfenben kan ses i pragteksemplarer. Udskæringerne kan være ganske dybe og meget detaljerede. Dekorationerne er som regel blomsterranker enten i

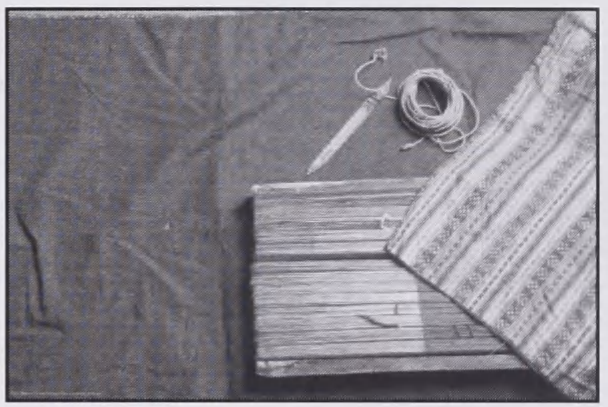

Fig. 15. Fint dekoreret svob til buddhistisk palmehåndskrift. Saratthasamuccaya (kommentarer til beskyttelsestekster) skrevet på pali i cambodjansk skrift. 1800-tallet.

stiliseret form eller med dyr og fugle mellem rankerne. Når håndskrifterne fik dækplader i kostbart materiale, kunne man yderlige berige håndskriftet ved at lade det første $\mathrm{og}$ sidste ubeskrevne blade blive dekoreret med bemaling. Ofte maledes en rød farve over hele forsiden af bladede og dernæst kunne de udsmykkes med kartouchelignende paneler i sort og mønstre i guldtusch. Mønstrene var plantelignende og undertiden ses buddhafigurer, dyr og fugle mellem planteranker.

Nogle dækplader af træ har en

Fig. 14. Cambodjansk palmehaindskrift med to elfenbensdakplader med dybe udskaringer. Buddhistiske fortallinger på pali med cambodjansk skrift. Sen 1800-tallet.

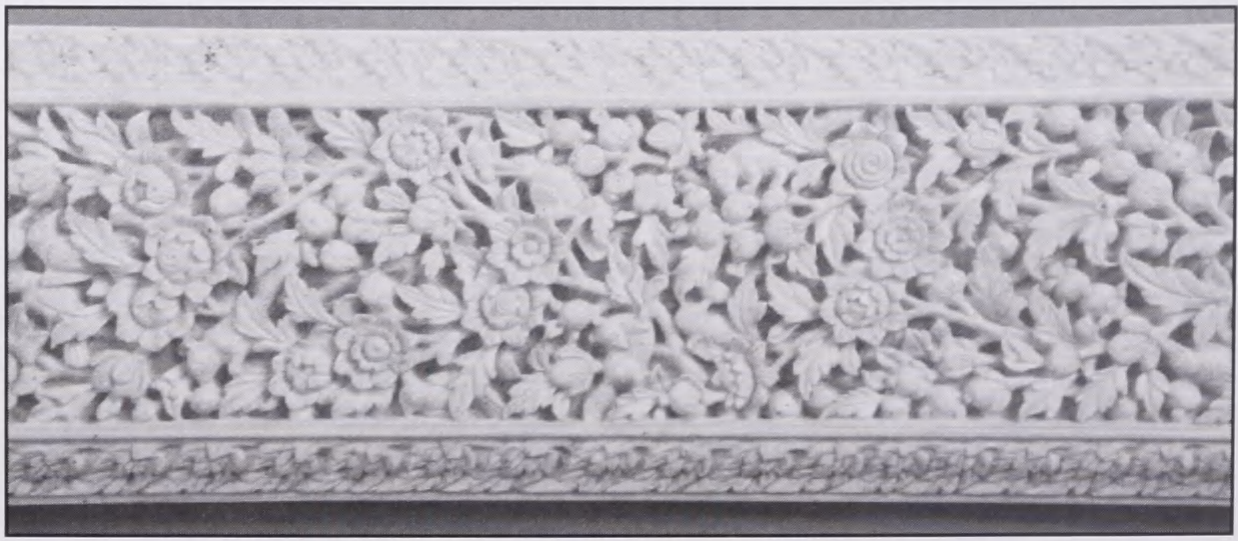




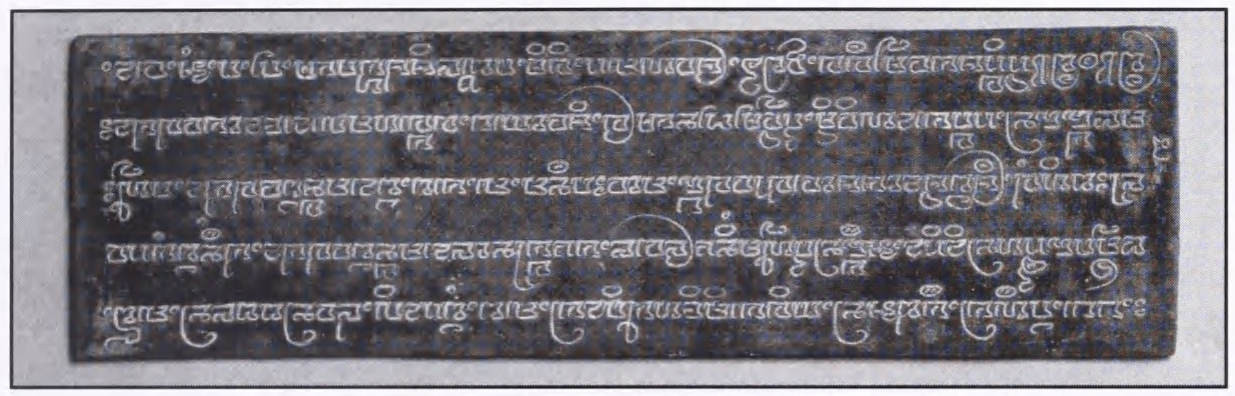

Fig. 16 Kobberplade dateret til 902 ined forste side af Kong Balitungs forfatning på oldjavanesisk.

sort bundfarve med dekorationer udført i guldtusch sat i og uden kartoucher, hvor mønstrene er planteagtige og geometriske. For yderlige at beskytte håndskrifterne blev de ofte svøbt i et farverigt klæde med geometriske mønstre i bånd eller firkanter.

\section{Indonesien}

I ndonesien består af en række forskellige kulturer med flere typer af bøger spredt over mange øer. Mange steder har man dog anvendt palmeblade som $\mathrm{i}$ resten af Sydøstasien. Som ofte er der tale om ret smalle palmeblade og indridsning er ligeledes mest almindelig.

På Java ser man mest palmeblade, men også bøger på metal kan forekomme. For metals vedkommende anvendtes både indridsning og støbning, og især de støbte eksempler er meget fine i deres skrift. Palmebladene har som regel indridsede tekster, der er blevet tydeliggjort ved indgnidning af sod.

Dækplader var enten uden overfladebehandling eller kunne være lakeret rød med overvejende plantemønstre i farver eller guldtusch. Nogle dækplader er dog udskåret i enkle kartoucheagtige paneler, hvor grønne felter står op mod en rød baggrund. Tit er den øverste dækplade relativ tyk med en udadbuet (konveks) profil.

\section{I det centrale Sumatra lever}

Batakfolket og deres traditionelle bøger er skrevet på bark. Barken blev banket, kogt, tørret og poleret således at tekstoverfladen er glat. Herpå skrev og malede man tekst og illustrationer med træpenne. Til længere tekster limede man barkstykkerne sammen, så der fremkommer en lang bane af bark. Denne bane foldedes i passende stykke alt afhængig af højden på bogen. Bogen fremstår således som et leporelloalbum (foldealbum). Teksten blev skrevet fra venstre mod højre enten vandret eller lodret i koloner. Bogen åbnes som når man trækker bælgen ud på en harmonika.

En del bøger er illustrerede, og det er især bøger med religiøst indhold, hvor man finder de overvejende rødbrune illustrationer. Som regel blev figurerne tegnet op i sort for derefter at blive udfyldt med rød-

Fig. 17. Profilerede dakplader af tra farvet med rod og gron omkring et javanesisk palmehåndskrift. Amir Hamza (Om helten Amir Hamza, der var onkel til profeten Muhammed). Tidlig 1800-tal.

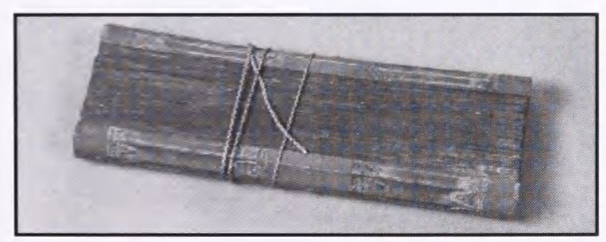




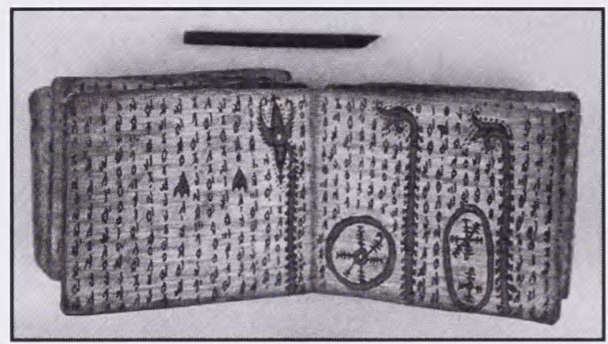

Fig. 18. Barkbog og skrivepen fra Batak-folket på Sumatra. Ritualtekst fra sen 1800-tal.

brun farve. Illustrationerne kunne være indført i selve teksten, men de kunne også optage en hel side og undertiden gå over to sider. Størrelsen på bøger kunne gå fra ganske små på $3,5 \times 3,5 \mathrm{~cm}$ til $22 \mathrm{~cm}$ i højden til $18 \mathrm{~cm}$ i bredden.

Barkbøgerne blev beskyttet af træplader, der var limet på for-og bagsiden af barkalbummet. Dækplader og album blev så holdt sammen af et flettet rørbånd. Mange af pladerne var enkle uden dekoration, men kunne dels have en fin hvælvet profil nærmest som et hustag og dels have ind- ridset/indskåret stiliserede plantemønstre. Det var almindeligt at polere den ydre overflade og farve dem mørke.

Batakfolket fremstillede også tekster på ben og på bambus. Tekster på disse materialer var af mere dagligdags karakter, som breve på bambus og beskyttelsesformularer på ben. Bambusteksterne var indridset på den runde yderside, således at bambusrøret bevarede sin form. Rørenes længde lå mellem $20 \mathrm{og} 40 \mathrm{~cm}$ og en diameter på omkring $5 \mathrm{~cm}$. I de tilfælde, hvor afskæringen af røret havde bevaret et af bambusknæene, blev dette poleret så de fine åretegninger stod smukt frem.

\section{Man anvendte også bambus-}

rørene til at indridse kalendere og magiske formularer. Magi var også forbundet med tekster på ben. Benstykkerne blev fremstillet af især bøffelknogler og havde mange udformninger. De kunne bl.a. tage form af en båd, en trekant eller et ritualredskab. Ofte blev teksten ledsaget af illustrationer i form af guder og ånder.

Fig. 19. Indgraveret Batakkalenderpå bambusror og ben. Kalenderen angiver gode og darlige dage for at rejse. Sen 1800-tallet.

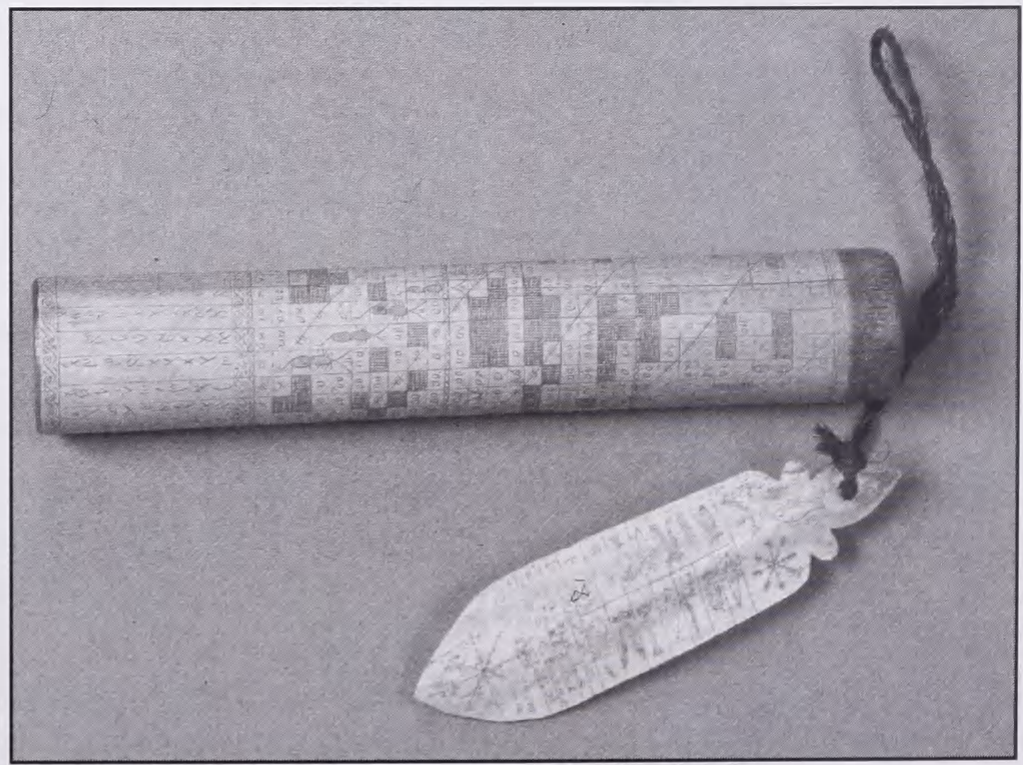

